\title{
Unusual Posttraumatic Delayed Cerebrospinal Fluid Rhinorrhea due to Gunshot Wound
}

\author{
Ateşli Silah Yaralanması Sonrası Geç Dönem Posttravmatik Rinore \\ Olgusu
}

Ali Erdem YILDIRIM ${ }^{1}$, Engin DURSUN² ${ }^{2}$, Denizhan DIVANLIOGLU ${ }^{1}$, Cagatay OZDOL $^{3}$, Osman Arıkan NACAR ${ }^{1}$, Ovunc Erdem CORAPCI ${ }^{1}$, Ahmed Deniz BELEN ${ }^{1}$

${ }^{1}$ Ankara Numune Research and Education Hospital, Department of Neurosurgery, Ankara, Turkey

${ }^{2}$ Recep Tayyip Erdogan University, Faculty of Medicine, Department of ENT, Rize, Turkey

${ }^{3}$ Antalya Research and Education Hospital, Department of Neurosurgery, Antalya, Turkey

Presented in: 26th Turkish Neurosurgical Congress, electronic poster presentation, 20 - 24 April 2012, Antalya, Turkey.

Corresponding Author: Ali Erdem YILDIRIM / E-mail: alierdemyildirim@gmail.com

\begin{abstract}
Delayed posttraumatic cerebrospinal fluid rhinorrhea (CSFr) without meningitis is considered to be relatively rare. However, even years after trauma, recurrence or delayed onset of CSFr and meningitis due to CSFr are possible. In this article, a case of delayed CSFr from the sphenoid sinus without meningitis three years after the transfacial gunshot wound is reported. Plain high-resolution computed tomography sections through the sphenoid sinus showed a bone defect at the roof with CSF-density fluid extending into the sphenoid sinus. Arachnoid membrane herniation into the sphenoid sinus was found and site of CSF fistula confirmed during the surgery. Skull base defect was reconstructed through an endoscopic approach without any complications and the patient was followed up for 12 months without recurrence. The cause, timing, clinical course and location of CSFr make this an apparently unique case. Patients with a skull base defect without CSFr should be closely followed up and may need further evaluation or management due to the possibility of CSFr development. The positive diagnosis of a CSFr raises the matter of choosing the adequate surgical approach for its repair. Endoscopic closure of CSFr is both safe and effective.
\end{abstract}

KEYWORDS: Rhinorrhea, Delayed, Posttraumatic, Gunshot wound, Meningitis, Sphenoid sinus

öz

Menenjit olmaksızın geç dönemde gelişen posttravmatik rinore nadir görülen bir durum olmasına rağmen, travmadan sonra yıllar içinde geç dönem rinore ve buna bağlı menenjit gelişmesi mümkündür. Bu makalede, 3 yıl önce yüz bölgesinde ateşli silah yaralanması meydana geldikten sonra, menenjit olmaksızın geç dönemde ortaya çıkan bir rinore olgusu sunulmaktadır. Hastanın yapılan incelemelerinde sfenoid sinüs tavanında kemik defekti ve bu defektten beyin omurilik sıvısı (BOS) kaçışı olduğu gösterilmiştir. Cerrahi sırasında sinüs içerisine araknoid membran herniasyonu izlenmiş olup, defektten BOS kaçağı olduğu da görülmüştür. Kafa tabanındaki defekt endoskopik endonazal transsfenoidal yaklaşım ile hiçbir komplikasyon olmadan tamir edilmiş ve hastanın 12 aylık takiplerinde hiçbir rekürrens izlenmemiştir. Rinorenin nedeni, zamanı, klinik seyri ve lokalizasyonu nedeniyle bu nadir görülen bir olgu olarak kabul edilebilir. Kafa tabanı defekti olan fakat rinore gözlenmeyen hastalar ileride rinore gelişme riski nedeniyle yakın takip edilmelidir. Rinore tanısı kesinleşen hastalarda, cerrahi yaklaşım yolları arasından, endoskopik endonazal yolla yapılan onarım hem efektif hem de güvenli olarak kabul edilmektedir.

ANAHTAR SÖZCÜKLER: Rinore, Geç dönem, Posttravmatik, Ateşli silah yaralanması, Menenjit, Sfenoid sinüs

\section{INTRODUCTION}

Cerebrospinal fluid (CSF) rhinorrhea ( $r$ ) is an uncommon but a challenging medical condition to treat. CSFr occurs due to the breakdown of the barriers separating the nasal cavity and the paranasal sinuses from the subarachnoid space, which are skull base, dura mater and arachnoid membrane (12). As it seem to be more clinically valuable, CSFr's classification is based on etiology such as accidental trauma, surgical trauma (iatrogenic), tumors, spontaneous and congenital rhinorrhea $(14,16)$.
Gunshot wounds (GW) of the head and neck region damaging neural and vascular tissues have high mortality and morbidity. Most common causes of civilian GW to the head are suicide attempts, homicides and negligent handling of firearms respectively. As they are $90 \%$ fatal, craniocerebral GWs are rarely managed in clinical practice (9). Depending on the course and trajectory, GW can involve the paranasal sinuses, orbita, cranial nerves or brain. The most often involved structures are the orbits, maxillary sinuses and frontal sinuses. The sphenoidal sinus is rarely damaged due to its deep location (5). However, the close relationship to the critical vascular and neural structures around the sphenoid sinus 


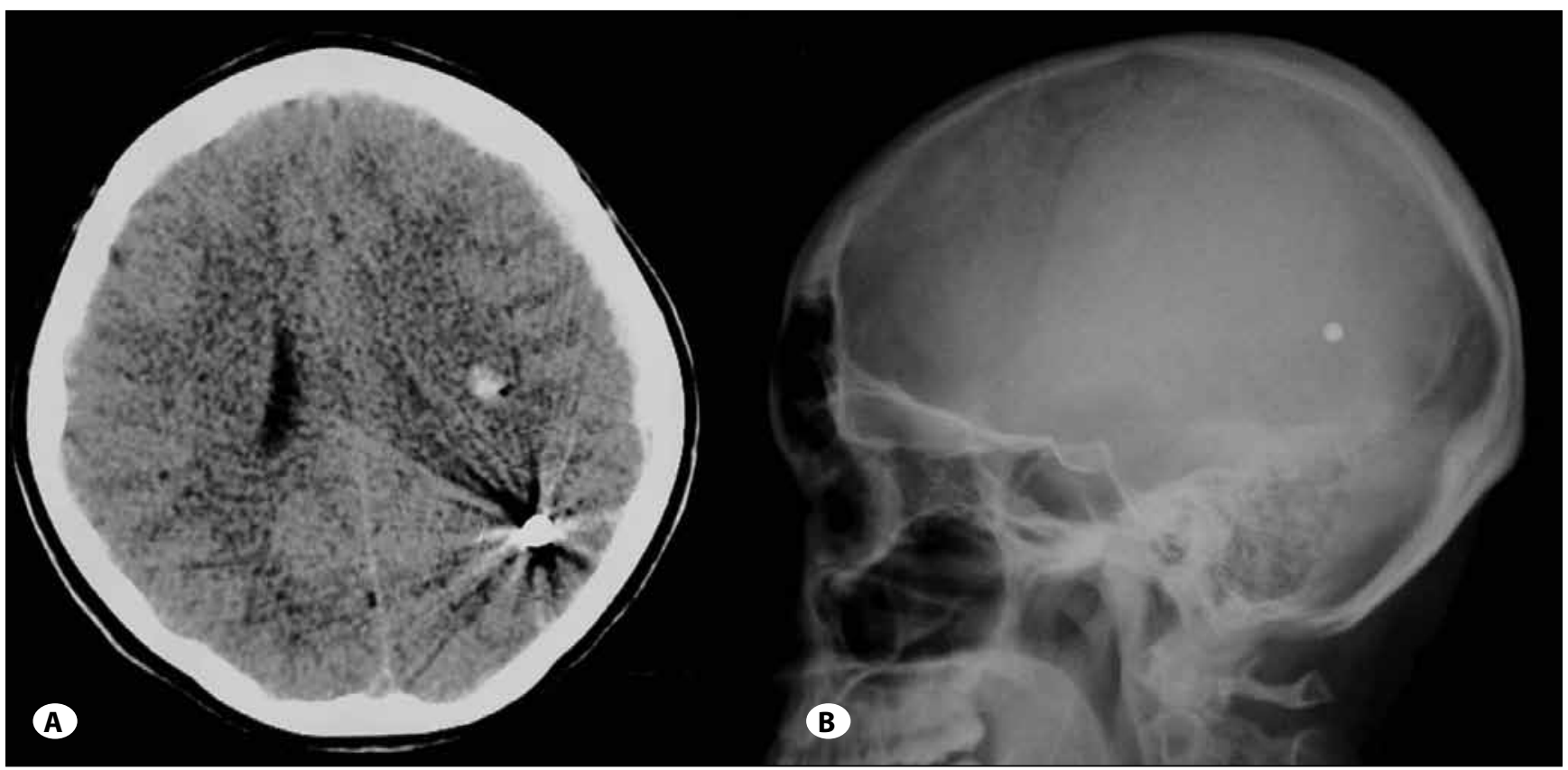

Figure 1: Samples from radiological evaluation of the patient in the emergency room $\mathbf{A}$ ) an axial non contrast computed tomography scan showing a bullet in the left occipital lobe and a small parenchymal hemorrhage inside the bullet tract. B) a lateral head $\mathrm{x}$-ray showing a bullet in occipital lobe.

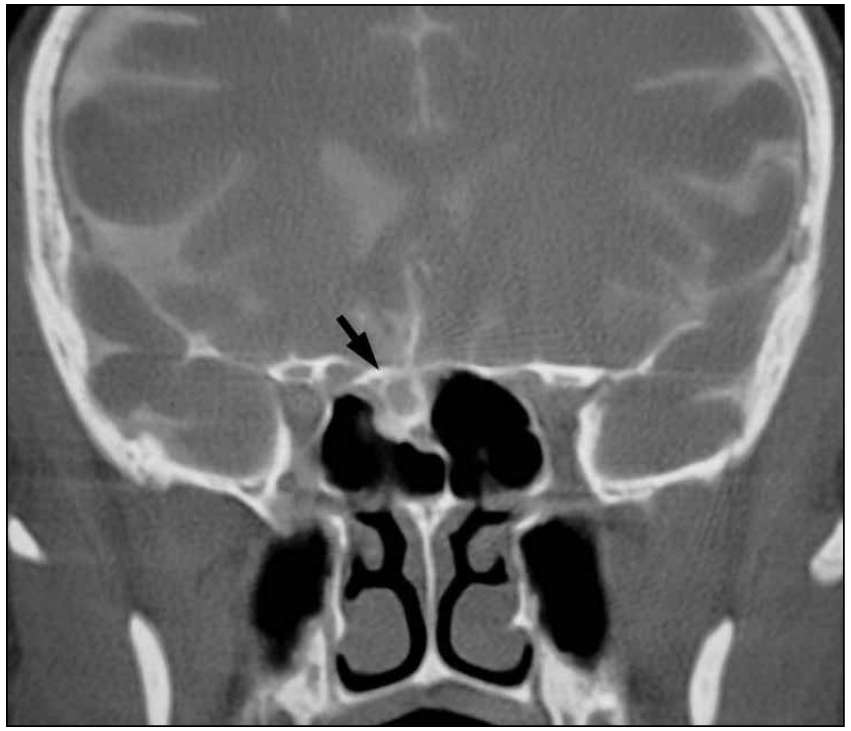

Figure 2: CT cisternography of the patient showing a sphenoid sinus roof defect and herniated pseudomeningocele beneath (arrow).

predisposes to potentially life-threatening consequences and sudden cerebral death occurs frequently by the involvement of the brain stem $(9,24)$. After a non-lethal craniocerebral GW, various collateral damages could happen in the neighboring structures. One of them is skull base injury, which could cause $\operatorname{CSFr}(9)$

In this article, a case of delayed CSFr from the sphenoid sinus three years after transfacial GW without meningitis is reported. The cause, time, clinical course and location of CSFr make this case apparently unique.

\section{CASE REPORT}

A 17-year-old female, previously healthy, was admitted to emergency unit of Neurosurgery Department because of a transfacial GW with disturbed consciousness four years ago. A bullet entry site was diagnosed during physical examination at the right maxillary region. A thorough neurological evaluation was completed and the overall Glasgow Coma Scale score was 8. There was no evidence of CSFr. The patient was evaluated with X-Ray and CT scan, showing multiple fractures, including right maxillary sinus, tuberculum sellae, sphenoid sinus and the floor of the orbit. Pneumocephalus was also observed and a bullet was visualized in the left occipital lobe (Figure $1 A, B)$. Angiography was not performed due to the lack of any evidence of vascular laceration. The patient stayed in the intensive care unit and was treated conservatively. Conservative management consisted of measures to reduce high intracranial pressure. These included bed rest, head end elevation and avoiding heavy lifting. Laxative treatment was given in order to decrease the straining and to avoid intracranial pressure increase. Appropriate antibiotics were used in order to prevent the development of any infection. A lumbar drain was not used. The patient recovered successfully and was discharged from the hospital.

The patient was admitted to the Neurosurgery Department again with a complaint of clear watery fluid dripping from her nose following an asymptomatic 3-year period after the GW. Neurologic examination was normal without any signs of 
symptoms of meningitis. There was a near constant drainage of a clear fluid, which had the chemical characteristics of cerebrospinal fluid. High-resolution CT sections without contrast enhancement through the sphenoid sinus showed an approximately $15 \mathrm{~mm}$ bone defect at the roof with a CSFdensity fluid extending into the sphenoid sinus. In an attempt to localizing the cranium defect associated with the leakage better, metrizamide-enhanced CT cisternography was performed. The left sphenoid sinus contained metrizamide, demarcating the site of leakage (Figure 2).

The endoscopes used were rigid scopes $4 \mathrm{~mm}$ in diameter, $18 \mathrm{~cm}$ in length, and equipped with zero, 30 and 45-degree lenses, according to different steps of the surgical operation.

The procedure was performed under general anesthesia with informed consent of the patient. CSFr was treated with a standard endoscopic endonasal transsphenoidal approach using the paraseptal route via bilateral nostrils $(6,7)$. After removal of the Vomer and sphenoid sinus septae, the sinus walls were visualized clearly and the defect due to the bullet track was localized on the sphenoidal roof. The defect's size was approximately $10 \mathrm{~mm}$ diameter and the arachnoid membrane was herniated like a meningoencephalocele. The CSFr was confirmed by visualizing the CSF flow through the defect with Valsalva maneuver. The margins of dura were clearly defined. Multilayer reconstruction was performed using fat graft, fascia lata, absorbable hemostat (Surgice ${ }^{\circledR}$ ), fibrin glue and porous polyethylene implant $\left(\right.$ Medpor $\left.^{\circledR}\right)$. Fat tissue and fascia lata were obtained by a nearly twocentimeter superiolateral thigh incision as needed. The rent in the dura was plugged snugly with fat tissue intradurally after removal of the mucosa of the sphenoid roof. The dura defect was patched indradurally with the fascia lata graft and the bone defect was reconstructed by Medpor ${ }^{\circledast}$. An extradural patch was also applied using another layer of fascia lata. The repaired area was supported with previously harvested fat fixed with Surgicel ${ }^{\circledR}$. Every step was augmented with fibrin glue. Finally, the sinus was filled with fibrin glue and held in place by a surgical nasal pack. Nor Nasal cavity was packed or Lumbar CSF diversion was used after the operation.

The postoperative course was uneventful and the patient was discharged without postoperative complications after four days of hospitalization. The CSFr disappeared, with no recurrence for more than 12 months following surgery.

\section{DISCUSSION}

About $70-80 \%$ of all CSF fistulas result from head injuries with skull base fractures after accidental traumas whereas CSF fistulae occurs in 2-3\% of the patients with head injury $(13,14,21)$.At least $85 \%$ of posttraumatic CSF leak cases are of the posttraumatic rhinorrhea. However, $60 \%$ of CSF fistulas occur within days after trauma, and $95 \%$ within 3 months, delayed CSF leakages may rarely occur after a few years $(7,17)$. Posttraumatic formation of a dural scar prevents leakage of CSF. As a result of tissue atrophy at the site of the dural lesion and microtrauma, CSFr can develop many years later (7).
The presence of uncontrollable clear watery fluid dripping from the nose and the presence of a halo sign on tissue paper with history of rhinologic or cranial base surgery, or following head trauma should arouse suspicion of $\operatorname{CSFr}(2,12,19)$. However, meningitis can be the sole symptom of a dural lesion although without surgical repair, the resulting dural scars often too thin to provide an adequate barrier against. An occult dural lesion is often only diagnosed after recurrent episodes of meningitis (17).

Successful surgical repair of CSFr depends on an accurate preoperative diagnosis and localization of the defected site (4). Nasal endoscopic examination coupled with maneuvers raising intracranial pressure, like bilateral jugular compression or coughing, may aid to diagnose and sometimes, by itself, exactly locate the leakage $(2,3)$. The presence of beta-2 transferrin in the nasal secretions strongly indicates CSFr $(19,25)$. Computed tomography (CT) and/or magnetic resonance imaging (MRI) might lead to the localization of a suspected CSFr if bony fractures and dehiscences, protruding encephaloceles, or tumors with bony erosions of the skull base are present, but does not establish CSFr $(4,19,25)$. As an indirect sign of posttraumatic, erosive or iatrogenic (surgical) dural dehiscence, intracranial air could be detected by CT or MRI (25).

High-resolution CT provides very sharp axial and coronal images which enables good definition of bony structures. On CT scans, a CSF leak may appear as an opacification of a sinus on CT scans which has to be differentiated from a mucosal reaction, a meningocele or a percolated CSF from a distal breach (4). However, CT scans have been reported to be able to identify the defects in $35-81 \%$ of the cases (2).

The gold standard for detecting CSFr has been considered to be CT cisternography with detection rates between $40 \%$ and $92 \%$, as if the leakage is active $(4,15,19)$. It is contraindicated in patients with high intracranial pressure and in those with spinal disorders (4)

When in doubt regarding the nature of the tissue, MRI can distinguish between cerebral tissue and retention material in the sinus close to the bony defect. MRI cisternography depends on T2-weighted sequences with fat suppression where CSF appears hyperintense without the need for an intrathecal contrast injection. In the diagnosis of CSFr, CT and MRI seem to be complementary because MRI only is insufficient to visualize bony details (4).

Most traumatic CSFr often stop spontaneously with conservative measures $(19,26)$. The leakage stops within 1 week in $70 \%$ of patients, within 3 months in $20-30 \%$, and within 6 months in most patients; leakage rarely recurs (26). However, spontaneous leaks in which CSFr develops days or weeks after trauma are less likely to stop (4). Conservative management consists of measures to reduce high intracranial pressure and includes bed rest, head end elevation, avoidance of straining and lifting of heavy weights and the use of laxatives $(4,20)$. The use of antibiotics is controversial 
(4). If CSFr continues for more than 8 days without treatment and presence of encephalocele or meningocele is associated, they lead to an increased risk of meningitis and encephalitis necessitating a surgical approach $(7,12)$. Because the brain herniates into the osteodural defect, it prevents the dura from healing itself naturally. An encephalocele or meningocele therefore need to be precisely repaired even if CSF leakage is not observed (7).

Surgical CSFr repair may be performed intracranially or extracranially $(2,19)$. Among the extracranial approaches, the transethmoidal and transfrontal routes are being progressively abandoned in favor of the nasal endoscopic approach (2). The success rate of nasal endoscopic approach is over $90 \%$ where it is accepted to be $60-73 \%$ for initial and $90 \%$ for multiple transcranial procedures $(2,11,19)$. The main advantage of transcranial approach is the ability to deal with other pathologies such as transcranial bleeding or tumors (19). The main disadvantage of the transcranial approach, in addition to the morbidity of craniotomy, is olfactory nerve damage during anterior cranial base mobilization from the level of the cribiform plate $(2,19)$. The transcranial approach using a bifrontal craniotomy is still widely used when large bony defects and the posterior frontal sinus wall repair is required. With this approach a wider exposure of the anterior cranial base can be provided for a more efficient repair and more sophisticated closure of skull base. As usual, careful selection of suitable cases affects the success of the outcomes (2).

The nasal endoscopic repair of CSFr presents, in many cases, a valuable alternative to the intracranial approach and different techniques and materials can be used for skull base reconstruction depending on surgeons' experiences $(1,2,5,6,8,18,22)$. Intradural and/or extradural closure of skull base defect and packing of the sella with or without packing of the sphenoid sinus can be the technical options (22). The majority of surgeons use a combination of autologous intrasellar grafts (fat, muscle, fascia lata, dermal grafts, lyophilised dura mater), a hemostatic agent (collagen sponge, oxidized cellulose, etc.) and/or some form of rigid/semi-rigid buttressing (nasal septum, sphenoid bone, titanium mesh, biodegradable plates or Foley catheter). The use of vascularized mucosal flaps, dural substitutes and tissue sealants are also described $(1,2,5,6,8,18,22)$. Even primary suturing of the dural defects has been reported (10). These can be deployed both with and without the assistance of lumbar CSF diversion $(5,8,22,23)$. In this case, multilayer reconstruction was performed for defect using fat graft, fascia lata, absorbable hemostat (Surgicel ${ }^{\circledR}$ ), fibrin glue and porous polyethylene implant $\left(\right.$ Medpor $\left.^{\circledast}\right)$ without lumbar CSF diversion.

Delayed posttraumatic CSFr without meningitis is rare. Neural tissue herniation into the paranasal sinuses after skull base defects could result in delayed CSFr. The patients with skull base defect without CSFr should be closely followed up and can be needed further evaluation or management because of possibility of developing CSFr. The positive diagnosis of a CSFr raises the matter of choosing the adequate surgical approach for its repair. Endoscopic closure of CSFr is both safe and effective.

\section{REFERENCES}

1. Cappabianca P, Cavallo LM, Valente V, et al: Sellar repair with fibrin sealant and collagen fleece after endoscopic endonasal transsphenoidal surgery. Surg Neurol 62:227-233; discussion 233, 2004

2. Castillo L, Jaklis A, Paquis P, Haddad A, Santini J: Nasal endoscopic repair of cerebrospinal fluid rhinorrhea. Rhinology 37:33-36, 1999

3. Dodson EE, Gross CW, Swerdloff JL, Gustafson LM: Transnasal endoscopic repair of cerebrospinal fluid rhinorrhea and skull base defects: A review of twenty-nine cases. Otolaryngol Head Neck Surg 111:600-605, 1994

4. Eid M, Ibrahim A, Elwany S, Hassab M, Khamis H: Evaluation of the role of high-resolution CT and MR cisternography in preoperative identification of skull base defect in cases of CSF rhinorrhea. EJENTAS 11:17-21, 2010

5. Esposito F, Dusick JR, Fatemi N, Kelly DF: Graded repair of cranial base defects and cerebrospinal fluid leaks in transsphenoidal surgery. Neurosurgery 60:295-303; discussion 303-294, 2007

6. Horiguchi K, Murai H, Hasegawa Y, Hanazawa T, Yamakami I, Saeki N: Endoscopic endonasal skull base reconstruction using a nasal septal flap: Surgical results and comparison with previous reconstructions. Neurosurg Rev 33:235-241; discussion 241, 2010

7. Kim HS, Hur JW, Lee JW, Lee HK: Extraordinarily long-term posttraumatic cerebrospinal fluid fistula. J Korean Neurosurg Soc 42:403-405, 2007

8. Kumar A, Maartens NF, Kaye AH: Reconstruction of the sellar floor using Bioglue following transsphenoidal procedures. J Clin Neurosci 10:92-95, 2003

9. Meco C, Tezcaner CZ, Tuna H, Gokcan K, Attar A, Anadolu $Y$ : Transfacial transsphenoidal gunshot wound: Endonasal endoscopic management. J Trauma 68:E94-98, 2010

10. Nishioka H, Izawa H, Ikeda $Y$, Namatame H, Fukami S, Haraoka $\mathrm{J}$ : Dural suturing for repair of cerebrospinal fluid leak in transnasal transsphenoidal surgery. Acta Neurochir (Wien) 151:1427-1430, 2009

11. Park Jl, Strelzow VV, Friedman WH: Current management of cerebrospinal fluid rhinorrhea. Laryngoscope 93:1294-1300, 1983

12. Presutti L, Mattioli F, Villari D, Marchioni D, Alicandri-Ciufelli M: Transnasal endoscopic treatment of cerebrospinal fluid leak: 17 years' experience. Acta Otorhinolaryngol Ital 29: 191-196, 2009

13. Rocchi G, Caroli E, Belli E, Salvati M, Cimatti M, Delfini R: Severe craniofacial fractures with frontobasal involvement and cerebrospinal fluid fistula: Indications for surgical repair. Surg Neurol 63:559-563; discussion 563-554, 2005

14. Sanderson JD, Kountakis SE, McMains KC: Endoscopic management of cerebrospinal fluid leaks. Facial Plast Surg 25: 29-37, 2009 
15. Schaefer SD, Diehl JT, Briggs WH: The diagnosis of CSF rhinorrhea by metrizamide CT scanning. Laryngoscope 90:871-875, 1980

16. Schlosser RJ, Bolger WE: Endoscopic management of cerebrospinal fluid rhinorrhea. Otolaryngol Clin North Am 39:523-538, 2006

17. Schick B, Weber R, Kahle G, Draf W, Lackmann GM: Late manifestations of traumatic lesions of the anterior skull base. Skull Base Surg 7:77-83, 1997

18. Sciarretta V, Mazzatenta D, Ciarpaglini R, Pasquini E, Farneti G, Frank G: Surgical repair of persisting CSF leaks following standard or extended endoscopic transsphenoidal surgery for pituitary tumor. Minim Invasive Neurosurg 53:55-59, 2010

19. Singh R, Hazarika P, Nayak DR, Balakrishnan R, Hazarika M, Singh A: Endoscopic repair of cerebrospinal fluid rhinorrhea - Manipal experience. Indian J Otolaryngol Head Neck Surg 61:14-18, 2009

20. Sharma DP, Singh D, Sinha S, et al. CSF rhinorrhea: An overview of endoscopic repair. IJNT 7:157-162, 2010
21. Talamonti G, Fontana R, Villa F, et al: "High risk" anterior basal skull fractures. Surgical treatment of 64 consecutive cases. J Neurosurg Sci 39:191-197, 1995

22. Tataranu L, Gorgan MR, Ciubotaru V, et al: Endoscopic endonasal transsphenoidal approach in the management of sellar and parasellar lesions: Indications and standard surgical technique (Part I). Romanian Neurosurgery 17:52-63, 2010

23. Van Aken MO, Feelders RA, de Marie Set al: Cerebrospinal fluid leakage during transsphenoidal surgery: Postoperative external lumbar drainage reduces the risk for meningitis. Pituitary 7:89-93, 2004

24. Wani NA, Khan AQ: Foreign body within sphenoid sinus: Multidetector-row computed tomography (MDCT) demonstration. Turk Neurosurg 20:547-549, 2010

25. Warnecke A, Averbeck T, Wurster U, Harmening M, Lenarz T, Stover T: Diagnostic relevance of beta2-transferrin for the detection of cerebrospinal fluid fistulas. Arch Otolaryngol Head Neck Surg 130:1178-1184, 2004

26. Welch KC, Stankiewicz J: CSF Rhinorrhea. http://emedicine. medscape.com/article/861126-overview 2011 